\title{
Rabies Virus Cross-Reactive Murine T Cell Clones: Analysis of Helper and Delayed-Type Hypersensitivity Function
}

\author{
H. BUNSCHOTEN, ${ }^{\prime}$ B. DIETZSCHOLD, ${ }^{2}$ I. CLAASSEN, ${ }^{1}$ R. KLAPMUTS, ${ }^{1}$ \\ F. UYTDEHAAG,' and A. OSTERHAUS ${ }^{\prime}$
}

\begin{abstract}
${ }^{I}$ National Institute of Public Health and Environmental Protection, Department of Immunobiology, Bilthoven, The Netherlands

${ }^{2}$ The Wistar Institute of Anatomy and Biology, Philadelphia, PA
\end{abstract}

ABSTRACT

Three $\mathrm{T}$ cell clones derived from rabies virus-immunized BALB/c mice were analysed for specificity and function. The clones proved to be broadly cross-reactive by responding to different rabies virus isolates (PM, ERA, CVS, HEP) and other representatives of the genus Lyssavirus, like the Duvenhage-6 (DUV6) and Mokola (MOK) viruses. The clones detected three different epitopes: an epitope expressed on the matrix protein (M) shared by PM, HEP, MOK and DUV6 viruses (clone AA8), an epitope expressed on the M-protein shared by PM, ERA, CVS, HEP and MOK viruses (clone 35A) and finally an epitope expressed on the glycoprotein (G-protein) shared by $P M$, ERA, CVS, HEP and MOK viruses (clone BG2). Antigen recognition of a11 clones proved to be MHC-restricted and they al1 displayed the $\mathrm{CD} 4^{+} \mathrm{CD} 8{ }^{-}$ phenotype. Intravenous inoculation of the $\mathrm{T}$ cells in syngeneic mice, which had been injected intracutaneously in the ear with HEP virus, resulted in a localized DTH reaction characteristic for $\mathrm{T}_{1} 1$ cells. In vitro, the clones were able to provide help to rabies virus-primed $B$ cells, resulting in the production of virus-specific antibodies directed against all the four structural proteins of rabies virus. Further analysis of this antibody response revealed that part of it was directed against antigenic determinants of the G-protein which induce virus neutralizing antibody.

\section{INTRODUCTION}

Rabies virus is a negative stranded RNA virus which infects the central nervous system of all warm-blooded species. The rabies virus genome encodes five proteins, including the large protein (L), which is an essential component of the rabies virus RNA-dependent RNA-polymerase (1), and four structural proteins: the glycoprotein (G), the nucleoprotein (N), the phosphoprotein (NS) and the matrix protein (M). Both virus neutralizing antibodies (VNA) and cell-mediated immunity appear to be important in the host defense against rabies virus infection (2): The G-protein has been regarded as the most relevant protein for the induction of protective immunity, since VNA have been shown thus far only to be induced by this protein $(3,4,5)$. Furthermore, The G-protein has been shown to elicit cytotoxic $\mathrm{T}$ lymphocytes (CTL), which may directly be involved in the clearance of rabies virus-infected cells $(6,7,8,9)$.

Recently, it became evident that not only the G-protein but also the $\mathrm{N}$-protein and synthetic peptides covering amino acid residues of the $\mathrm{N}$ - 
protein can induce protection against lethal rabies virus infection in mice (10). The mechanisms involved in this induction of protective immunity are not yet understood, but may include the generation of $\mathrm{N}$-specific CTLs and/or the generation of $\mathrm{N}$-specific $\mathrm{T}$ helper cells $\left(\mathrm{T}_{\mathrm{H}}\right)$, that stimulate VNA producing $B$ cells upon rabies virus challenge. Evidence that the development of humoral immunity against rabies virus, including the production of G-protein-specific VNA, indeed depends on the activity of $T_{H}$ cells, originates from several in vivo and in vitro experiments using polyclonal cell suspensions $(11,12,13,14)$.

Previously, we have also demonstrated that human $T$ cell clones recognizing rabies virus antigen are able to assist rabies virus-immune $B$ cells in the production of specific antibodies (15). However, the role of such $T$ cells in in vivo protection cannot be evaluated. Therefore we have also established murine rabies virus-specific $\mathrm{CD}^{+}{ }^{+} \mathrm{CD} 8^{-} \mathrm{T}$ cell clones. In the present report, we have analyzed three $T$ cell clones, displaying specificity for the rabies virus membrane associated proteins $G$ and $M$. The clones were shown to provide help to primed $B$ cells in vitro and to mediate a virus-specific delayed-type hypersensitivity reaction (DTH) in vivo.

\section{MATERIALS AND METHODS}

Mice

BALB/c mice, 6 to 12 weeks old, were bred at the animal facilities of the National Institute of Public Health and Environmental Protection (Bilthoven, The Netherlands). BALB.B, B10.D2 and C57b1/6J mice, 6 to 8 weeks old, were purchased from Harlan/Olac (Bicester, Oxon, UK).

\section{Viruses and antigens}

The PM virus strain of rabies virus (PM/w1-38-1503-3m) was propagated in dog kidney cells (PM-DKCV), in human diploid cells (PM-HDCV) or in Vero cells (PM-VRV), purified and $\beta$-propiolacton (BPL) inactivated as described previously (16). The potency of rabies virus vaccines was $3.10 \mathrm{IU} / \mathrm{dose}$ for PM-DKCV, $3.73 \mathrm{IU} /$ dose for PM-HDCV and $3.16 \mathrm{IU} /$ dose for PM-VRV (PM-HDCV and PM-VRV were kindly provided by $\mathrm{Dr}$. Lombard, Institut Mérieux, Lyon, France). ERA, CVS and PM (PM-BHK) virus strains of rabies virus and the rabies virus-related Mokola (MOK) and Duvenhage-6 (DUV6) virus strains were propagated in BHK-21 cell culture monolayers, BPL-inactivated and adjusted to a protein concentration of $100 \mu \mathrm{g} / \mathrm{ml}$ as previously described (3). For use in cell cultures, these antigen preparations were diluted in RPMI 1640 tissue culture medium. Unless otherwise stated the preparations were used at final concentrations of 0.01 IU per culture, corresponding to about $1 \mu \mathrm{g}$ per culture of PM-DKCV. The Flury HEP virus strain of rabies virus was passaged three times by intracerebral inoculation in suckling BALB/c mice. Stock viral pools were prepared as 108 mouse brain suspension and stored at $-70^{\circ} \mathrm{C}$ in minimal essential medium, containing 28 horse serum. The Edmonston strain of measles virus was cultured on Vero cells and purified by density centrifugation on sucrose as described (17). Purified measles was subsequently inactivated by UV-irradiation $\left(1.5 \times 10^{-3} \mu \mathrm{W} / \mathrm{mm}^{2}\right)$. Rabies virus proteins were purified by preparative SDS-polyacrylamid gel electrophoresis as recently described (18).

\section{Generation and phenotypic characterization}

$\mathrm{BALB} / \mathrm{c}$ mice were immunized twice intraperitoneally (i.p.) with $150 \mu \mathrm{g}$ of PM-DKCV at 2 week interval. Two weeks after the last immunization spleen cells were isolated by sedimentation on a density gradient (Lympholyte $M$, Cedarlane Laboratories, Hornby, Canada). Cells were cultured in flatbottomed 24-well plates (Costar Data Packaging, Cambridge, MA, USA) at a density of $3 \times 10^{6}$ cells/we11 in the presence of $1 \mu \mathrm{g} /$ well PM-DKCV in 
Iscove's modified Dulbecco's medium, supplemented with $2 \mathrm{mM}$ L-glutamine, penicillin $\left(100\right.$ units/m1), streptomycin $(100 \mu \mathrm{g} / \mathrm{ml}), 5 \times 10^{-5} \mathrm{M} 2-$ mercaptoethanol and $10 \%$ fetal calf serum (referred to as complete medium). After four days in culture at $37^{\circ} \mathrm{C}$, cells were harvested, washed twice with medium and cultured under limiting dilution conditions in 96 -well roundbottomed microtitre plates (Greiner Labor Technik, Nurtingen, FRG). Each well received $3 \times 10^{5}$ irradiated (1500 rads) syngeneic spleen cells, $1 \mu \mathrm{g}$ PMDKCV and $58(\mathrm{v} / \mathrm{v})$ conditioned medium from rat splenocytes containing 200 $\mathrm{U} / \mathrm{ml}$ Interleukin 2 (Il-2). Fourteen to twenty-one days later, growing clones were expanded, kept at a density of $1 \times 10^{4}$ cells per well and restimulated with PM-DKCV every 10-14 days of culture.

Characterization of phenotypic markers of the growing $T$ cell clones was performed by incubation of the cells with rat anti-Thy 1.2 , anti-CD8 and anti-CD4 monoclonal antibodies (MAbs) and a subsequent incubation with fluorescein isothiocyanate (FITC)-conjugated goat anti-rat immunoglobulin according to the procedure recommended by the manufacturer (BecktonDickinson, Immunocytometry systems, Mountain View, California, USA).

\section{Proliferation assays}

T cell clones were harvested 7 days after the latest stimulation with PM-DKCV and washed three times. $10^{4}$ cloned $\mathrm{T}$ cells were cultured in roundbottomed wells in the presence of $3 \times 10^{5}$ syngeneic irradiated (1500 rads) spleen cells and antigen preparations in complete medium. After $48 \mathrm{hrs}$ incubation at $37^{\circ} \mathrm{C}$ in a humidified atmosphere of $58 \mathrm{CO}_{2}$ in air, cultures were pulsed with $0.5 \mu \mathrm{Ci}{ }^{3} \mathrm{H}$-thymidine over the last $16^{2} \mathrm{hrs}$ of culture. Cells were harvested onto glass fibre filters and the incorporated radioactivity was determined in a liquid scintilation counter. Results are expressed as the mean $\pm S . D$. of triplicate cultures.

\section{Helper activities of $T$ cell clones}

Spleens from BALB/c mice immunized twice i.p. at four week interval with $150 \mu \mathrm{g}$ PM-DKCV were isolated and homogenized 4 weeks after the last immunization. Splenocytes were depleted and homogenized 4 weeks after the last immunization. Splenocytes were depleted of $\mathrm{T}$ cells by treatment with a rat MAb to Thy 1.2 (anti-Thy 1.2, Becton-Dickinson, Mountain View, California, USA) for $1 \mathrm{hr}$ at $4^{\circ} \mathrm{C}$, followed by treatment with $10 \%$ Low-Tox rabbit complement (Cedarlane Laboratories Ltd., Hornby, Canada) for 30 min at $37^{\circ} \mathrm{C}$. Non-T cell suspensions were shown to contain less than 18 thy $1.2^{+}$ $\mathrm{T}$ cells as determined in FACS-analysis. $2 \times 10^{5}$ non-T cells were incubated in complete medium, together with $10,10^{2}, 10^{3}$ cloned $\mathrm{T}$ cells or without $\mathrm{T}$ cells and in the presence of $1 \mu \mathrm{g}$ PM-DKCV or without antigen in 96-well flat-bottomed microtitre plates (Greiner, Labor Technik, Nurtingen, FRG). In another assay the rabies virus primed non- $T$ cell suspension was mixed (1:1) with $\mathrm{T}$ cell-depleted spleen cells from BALB/c mice immunized twice subcutaneously at an interval of four weeks with $30 \mu \mathrm{g} \mathrm{UV}$-inactivated measles virus in complete Freund adjuvant ( $\mathrm{CFa}$ ) and incomplete Freund adjuvant respectively. This mixed non-T cell population was incubated at $5 \times 10^{5}$ cells per well with $10^{2}$ cloned $\mathrm{T}$ cells or without $\mathrm{T}$ cells and in the presence of optimal concentrations of PM-DKCV ( $1 \mu \mathrm{g})$, measles virus ( $7 \mathrm{ng}$ ) or both PM-DKCV and measles virus as stimulating antigens. After 7 days of culture at $37^{\circ} \mathrm{C}$, culture supernatants were harvested and assayed for PMDKCV and measles virus binding IgG in solid phase immunoassays (ELISA) as previously described $(2,20)$. titres were expressed as the reciprocal of the highest dilution giving more than three times background values and determined by calculating the value obtained with triplicate cultures. SDSpolyacrylamide gel electrophoresis and Western blot analysis of culture supernatants was performed as recently described (19). Virus neutralizing activity in culture supernatants was determined in a rapid fluorescent focus inhibition test (RFFIT) as previously described by others (20). 
T cell clones were harvested 7 days after the latest stimulation with PM-DKCV, washed three times and resuspended in Iscove's modified Dulbecco's medium. Viable cloned $\mathrm{T}$ cells $\left(1 \times 10^{6}\right)$ were inoculated intraveneously into 10 weeks old BALB/c mice. A second group of BALB/c mice received no $T$ cells. These mice were immunized prior to cell transfer intraperitoneally with $150 \mu \mathrm{g}$ PM-DKCV. All mice were injected by intracutaneous injection with Flury HEP virus or control brain suspension in a volume of $15 \mu 1$ in the left and right ear respectively. A Mitutoyo engineering micrometer was used to measure ear swelling at different times after challenge. Ear swelling is expressed in $\mu \mathrm{m}$ as the mean $\pm S . D$. per group of three mice.

\section{RESULTS}

Generation and phenotypic characterization of rabies virus-specific $T$ cell clones

Splenocytes of PM-DKCV-immunized BALB/c mice, were restimulated in vitro with PM-DKCV and subsequently cloned at limiting dilutions. Of 384 wells initially seeded at 100 cells per well, significant cell growth was noted in six $(1,68)$. According to Poisson's distribution, these cells were

TABLE 1

Antigen Specificity of Rabies Virus-specific T Ce11 Clones

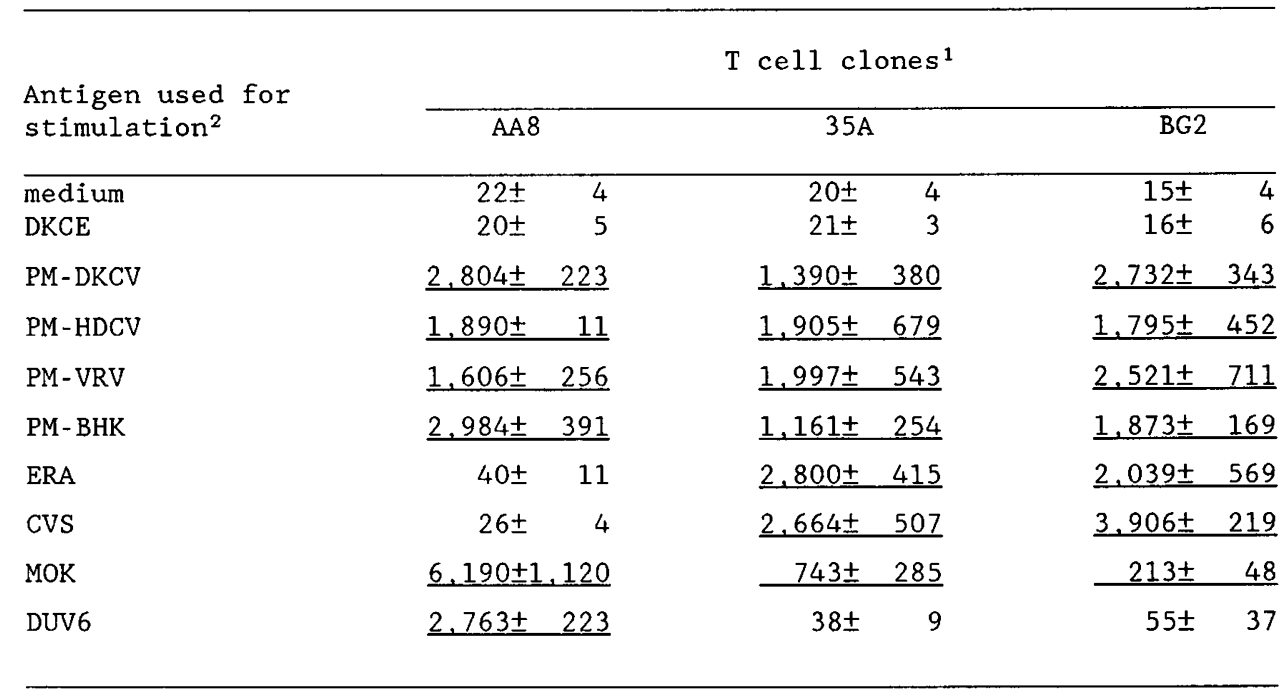

$110^{4} \mathrm{~T}$ cells were cultured for $72 \mathrm{hrs}$ in the presence of $2.510^{5}$ irradiated syngeneic spleen cells and antigen and then pulsed with 0.5 $\mu \mathrm{Ci} /$ wel1 ${ }^{3} \mathrm{H}$-thymidine for $16 \mathrm{hrs}$, as described in "Materials and Methods". Results are expressed as mean c.p.m \pm S.D. of triplicate cultures.

2 Antigens: DKCE, dog kidney cell extract $30 \%$ (v/v), PM-DKCV, rabies virus PM-strain (dog kidney cell vaccine) $1 \mu \mathrm{g} /$ well or $0.01 \mathrm{IU} / \mathrm{we} 11$, PM-HDCV, rabies virus PM-strain (human diploid cell vaccine) 0.01 IU/we11, PM-VRV, rabies virus PM-strain (Vero cell vaccine) $0.01 \mathrm{IU} /$ well, $\underline{\text { PM-BHK, rabies }}$ virus PM-strain (grown on BHK-21 cells) $0.25 \mu \mathrm{g} /$ well, ERA, rabies virus ERA-strain $0.25 \mu \mathrm{g} /$ we 11 , CVS, rabies virus CVS-strain $0.25 \mu \mathrm{g} /$ well, MOK, Mokola virus $0.25 \mu \mathrm{g} /$ we11, DUV6, Duvenhage- 6 virus $0.25 \mu \mathrm{g} /$ wel1. 
considered to be clonally expanded ( $>998)$. Three stable $\mathrm{T}$ cell clones (AA8, $35 \mathrm{~A}$ and $\mathrm{BG} 2$ ) were selected for the present study and were maintained in culture by restimulation with fresh irradiated syngeneic spleen cells as APC, PM-DKCV and I12-containing supernatant from rat splenocytes. By FACS analysis, clones $A A 8,35 \mathrm{~A}$ and $\mathrm{BG} 2$ were shown to be reactive with Thy 1.2and CD4-specific MoAbs and did not react with a CD8-specific MoAb, consistent with a $\mathrm{CD} 4^{+} \mathrm{CD} 8^{-}$surface phenotype of murine $\mathrm{T}_{\mathrm{H}}$ cells (results not shown).

In proliferation assays all clones showed a response to inactivated PM virus, produced in four different cell substrates (PM-DKCV, PM-HDCV, PM-VRV and PM-BHK), and were unreactive to dog kidney cell components (DKCE) present in PM-DKCV (table 1). Further determination of antigen specificity showed, that all clones also responded to inactivated rabies virus-related MOK virus, that clones $35 \mathrm{~A}$ and $\mathrm{BG} 2$ also responded to inactivated ERA and CVS viruses and that clone AA8 also responded to the rabies virus-related DUV6 virus (table 2).

In proliferation assays, determining the polypeptide specificity of the clones with a set of purified proteins available for the ERA, MOK and PM viruses, clones AA8 and $35 \mathrm{~A}$ were shown to display specificity for the Mprotein, by proliferating to $P M$ virus or ERA virus derived $M$ respectively (table 2). Clone BG2 showed specificity for the G-protein, since this clone proliferated to ERA-G and not to other purified ERA-proteins (table 2).

TABLE 2

Protein Specificity of $\mathrm{T}$ Cell Clones

\begin{tabular}{|c|c|c|c|c|c|}
\hline \multirow{3}{*}{$\begin{array}{l}\text { Antigen used for } \\
\text { stimulation }{ }^{2} \\
\text { medium } \\
\text { ERA }\end{array}$} & \multicolumn{5}{|c|}{$\mathrm{T}$ cell clones ${ }^{1}$} \\
\hline & AA8 & \multicolumn{2}{|c|}{$35 \mathrm{~A}$} & \multicolumn{2}{|l|}{ BG2 } \\
\hline & $\begin{array}{c}237 \pm \\
\text { N.D. }{ }^{3}\end{array}$ & $\begin{array}{r}12 \pm \\
1,011 \pm\end{array}$ & $\begin{array}{l}3 \\
9\end{array}$ & $\begin{array}{r}39 \pm \\
957 \pm\end{array}$ & $\begin{array}{r}8 \\
259\end{array}$ \\
\hline ERA-G & N.D. & $27 \pm$ & 4 & $\underline{823 \pm}$ & 324 \\
\hline ERA - N & N.D. & $76 \pm$ & 21 & $82 \pm$ & 32 \\
\hline ERA-NS & N.D. & $68 \pm$ & 15 & $31 \pm$ & 8 \\
\hline ERA-M & N.D. & $646 \pm$ & 90 & $65 \pm$ & 22 \\
\hline MOK & $5,356 \pm 1,136$ & N.I & & N.D. & \\
\hline PM-BHK & $6,366 \pm 1,801$ & N.I & & N.D. & \\
\hline MOK-G & $261 \pm \quad 54$ & N.I & & N.D. & \\
\hline MOK-N & $356 \pm \quad 41$ & N.I & & N.D. & \\
\hline MOK-NS & $190 \pm \quad 12$ & N.I & & N.D. & \\
\hline PM-M & $3,284 \pm \quad 327$ & N.I & & N.D. & \\
\hline
\end{tabular}

$110^{4} \mathrm{~T}$ cells were cultured for $72 \mathrm{hrs}$ in the presence of $2.510^{5}$ irradiated syngeneic spleen cells and antigen and then pulsed with 0.5 $\mu \mathrm{Ci} /$ well ${ }^{3} \mathrm{H}$-thymidine for $16 \mathrm{hrs}$, as described in "Materials and Methods". Results are expressed as mean c.p.m \pm S.D. of triplicate cultures.

$20.25 \mu \mathrm{g} /$ well of the rabies virus strains ERA and PM (PM-BHK), the rabies virus-related Mokola virus (MOK), and the respective SDS-PAGE purified glycoproteins (G), nucleoproteins (N), phosphoproteins (NS) and matrix proteins (M) .

$3 \mathrm{ND}=$ not determinated 
Spleen cells from four inbred mouse strains were used as a soyrce of irradiated APC. Spleen cells from BALB/C (H-2 ${ }^{\mathrm{C}}$ ) mice and B10.D2 (H-2 ${ }^{\mathrm{d}}$ ) mice stimulated the proliferation of clones $A A 8,35 A$ and $B G 2$ in the presence of PM-DKCV, wheras spleen cells from BALB.B $\left(\mathrm{H}-2^{\mathrm{b}}\right)$ mice or $\mathrm{C} 57 \mathrm{bl} / 6 \mathrm{~J}\left(\mathrm{H}-2^{\mathrm{b}}\right)$ mice did not (table 3 ).

TABLE 3

MHC-restriction of Antigen Recognition by $\mathrm{T}$ Cell Clones

Antigen presenting cells from ${ }^{2}$

\begin{tabular}{lcccc}
\hline T cel1 clones & BALB/c & BALB.B & B10.D2 & C57b1/6J \\
\hline AA8 & $\underline{68.5}$ & 0.6 & $\underline{100.2}$ & 1.0 \\
35A & $\underline{29.1}$ & 1.3 & $\underline{156.7}$ & 0.9 \\
BG2 & $\underline{32.9}$ & 0.5 & $\underline{115.8}$ & 0.6
\end{tabular}

$110^{4}$ cells were cultured for $72 \mathrm{hrs}$ in the presence of $2.510^{5}$ irradiated spleen cells from BALB/c (H-2 $\left.2^{\mathrm{a}}\right)$, BALB.B (H-2 $\left.{ }^{\mathrm{b}}\right), \mathrm{B} 10 . \mathrm{D} 2\left(\mathrm{H}-2^{\mathrm{d}}\right)$ or $\mathrm{C} 57 \mathrm{bl} / 6 \mathrm{~J}$ $\left(\mathrm{H}-2^{\mathrm{b}}\right)$ mice and in the presence of PM-DKCV or medium only.

2 The results are expressed by the stimulation index as the mean value of triplicate cultures stimulated with PM-DKCV divided by the mean value of triplicate cultures stimulated with medium only.

\section{Functional analysis of $T$ cell clones in vitro}

In order to determine whether clones $A A 8,35 \mathrm{~A}$ and $\mathrm{BG} 2$, displaying the $\mathrm{CD}^{+}{ }^{+} \mathrm{CD}^{-}$phenotype could indeed act as $\mathrm{T}_{\mathrm{H}}$ cells for rabies virus-specific $\mathrm{B}$ cells, in vivo primed spleen cells were depleted of $\mathrm{T}$ cells (further referred to as non- $T$ cells) and cultured with different numbers of $T$ cells in the presence of PM-DKCV.

Clearly, no PM-DKCV binding IgG could be detected in supernatant fluids, when the $T$ cell clones were cultured in the presence of the non- $T$ cells without PM-DKCV or when the non-T cells were cultured with PM-DKCV in the absence of $T$ cell clones (figure 1). The non-T cells were found to produce PM-DKCV binding IgG (figure 1), when cultured with clones AA8, 35A or BG2 (10-1000 cells/well) in the presence of PM-DKCV ( $1 \mu \mathrm{g} /$ well). The presence of VNA in supernatant fluids of non-T cells, which had been cultured in the presence of PM-DKCV and clones AA8, 35A and BG2 could be demonstrated in RFFIT. These supernatant fluids neutralized the CVS virus, while supernatant fluids of non-T cells, cultured in the absence of PM-DKCV with clones $A A 8,35 A$ and $B G 2$ did not (table 4). In Western blot analysis it was observed that supernatant fluids of cultures of non-T cells, which had been cultured in the presence of PM-DKCV and clones AA8, 35A and BG2 displayed reactivity for all four structural proteins of PM virus (figure 2).

To analyze the specificity of the helper activity of the clones in more detail, clone $35 \mathrm{~A}$ was cultured with a mixture in vivo rabies virus-primed and in vivo measles virus-primed non-T cells and in the presence of either PM-DKCV, measles virus or both antigens. As a control a measles virusspecific $T_{H}$ clone $10.5 \mathrm{Cl}$ was used (kindly provided by $\mathrm{Dr}$. P. de Vries, National Institute of Public Health and Environmental Protection, Bilthoven, The Netherlands). Culture supernatant fluids of triplicate cultures were assayed for both rabies virus- and measles virus-specific IgG antibody production. The results of these experiments show that rabies virus-specific $T$ cells and measles virus-specific $T$ cells can assist $B$ cells primed with rabies virus and measles virus antigens in specific antibody production provided both antigens (PM-DKCV and measles virus) are 


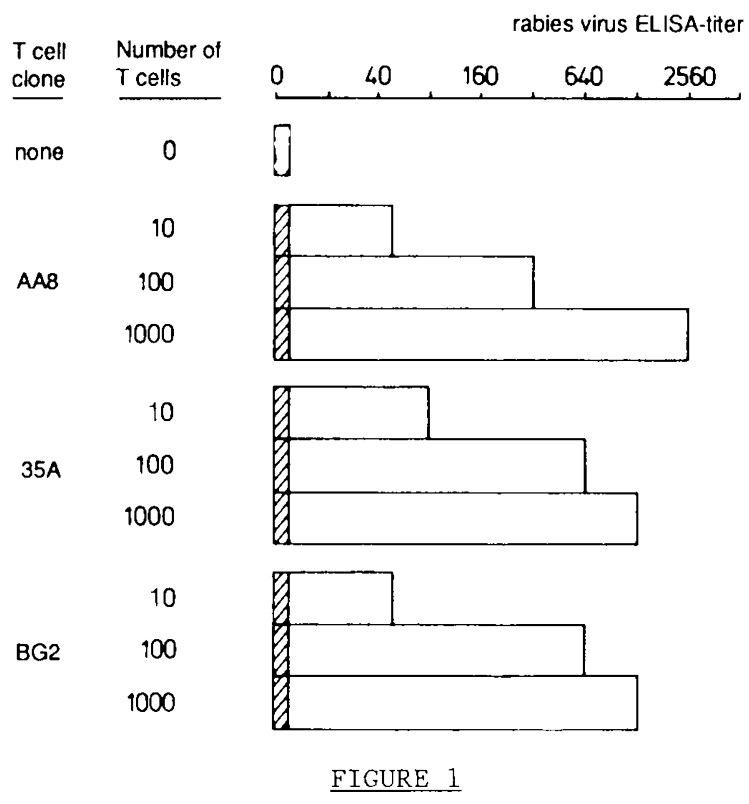

In vitro helper function of rabies virus-specific $T$ cell clones. Splenocytes of PM-DKCV-immunized mice were depleted of $\mathrm{T}$ cells. These were cultured at $2 \times 10^{5}$ cells/well with $10,10^{2}, 10^{3}$ cells/well of $\mathrm{T}$ cell clones AA8, 35A, BG2 or no $T$ cells in the presence (口) or absence ( $\square$ ) of PM-DKCV. After 7 days of culture, supernatant fluids were harvested and then assayed for PM-DKCV binding IgG in ELISA. The results represent the mean antibody titre of supernatant fluids obtained from triplicate cultures.

present in culture (figure 3). However, when cells were cultured in the presence of either PM-DKCV or measles virus antigen only rabies virusspecific or measles virus-specific IgG antibody respectively was detectable in culture supernatant fluids (figure 3 ).

TABLE 4

T Cell Help for Neutralizing Antibody Response

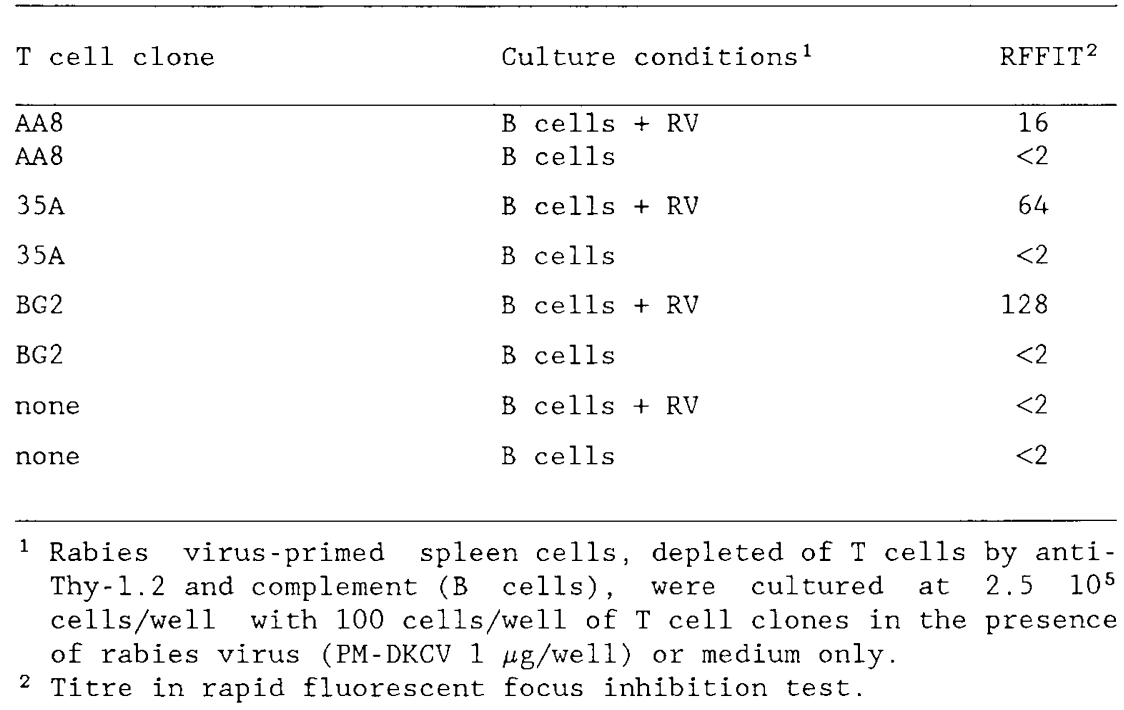




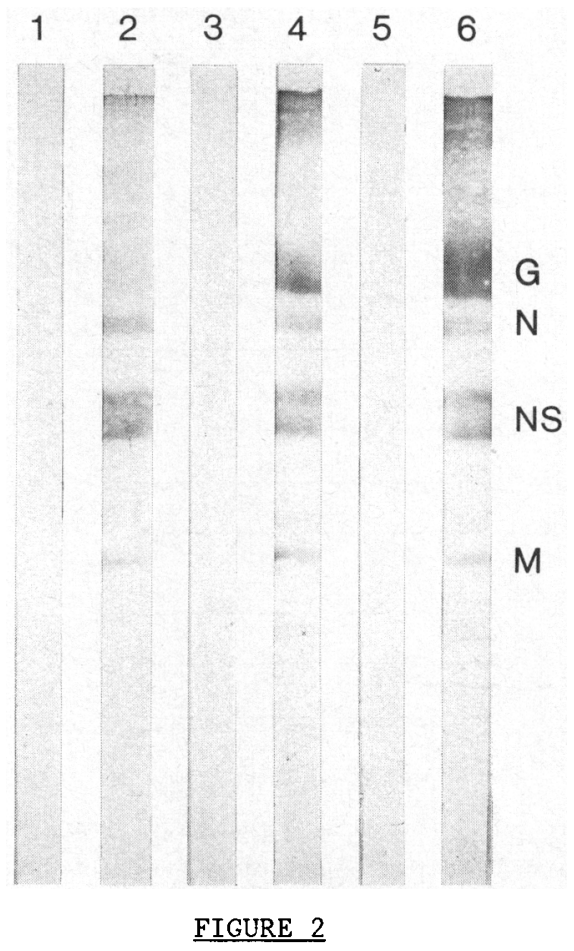

Western blot analysis of the in vitro anti-rabies virus response. $T$ cell clones were cultured as described in the "Legend to Figure 1 " with the non-T cell fraction of splenocytes isolated from PM-DKCV-immunized mice. Lanes 1, 3, 5: reactivities of supernatant fluids of cultures stimulated in the absence of PM-DKCV with clone AA8 (lane 1), 35A (lane 2) and BG2 (lane 3). Lanes 2, 4, 6: reactivities of supernatant fluids of cultures stimulated in the presence of PM-DKCV with clone AA8 (lane 2), 35A (1ane 4) and BG2 (lane 6), showing the glycoprotein (G), the nucleoprotein (N), the phosphoprotein (NS) and the matrix protein (M).

\section{Functional analysis of $\mathrm{T}$ cell clones in vivo}

The ability of rabies virus-specific $\mathrm{T}$ cell clones to mediate a DTH reaction in vivo was studied. To this end BALB/c mice were inoculated intraveneously with $10^{6} \mathrm{~T}$ cells and subsequently injected intracutaneously in the ear with a brain suspension containing HEP virus or control brain suspension. As shown in figure 4, rabies virus-specific ear swelling was observed with clone AA8, with clone $35 \mathrm{~A}$ and with clone BG2 at levels comparable to those found in PM-DKCV-immunized mice.

\section{DISCUSSION}

In this paper, we have characterized three murine $T_{H}$ clones generated against the PM strain of rabies virus. The clones were shown to recognize the immunizing virus in a MHC-restricted manner by a reguirement for the virus to be presented in association with APC of the $\mathrm{H}-2$ haplotype. In vitro and in vivo, the clones were found broadly cross-reactive with other rabies virus strains (ERA, CVS, HEP) and with rabies virus-related Lyssaviruses (DUV6, MOK), which indicates that these different serotypes share $\mathrm{T}$ cell epitopes.

Recently, similar observations were reported with human $\mathrm{T}$ cell clones by Celis et al. $(8,9)$. The viral epitopes responsible for the activation of 


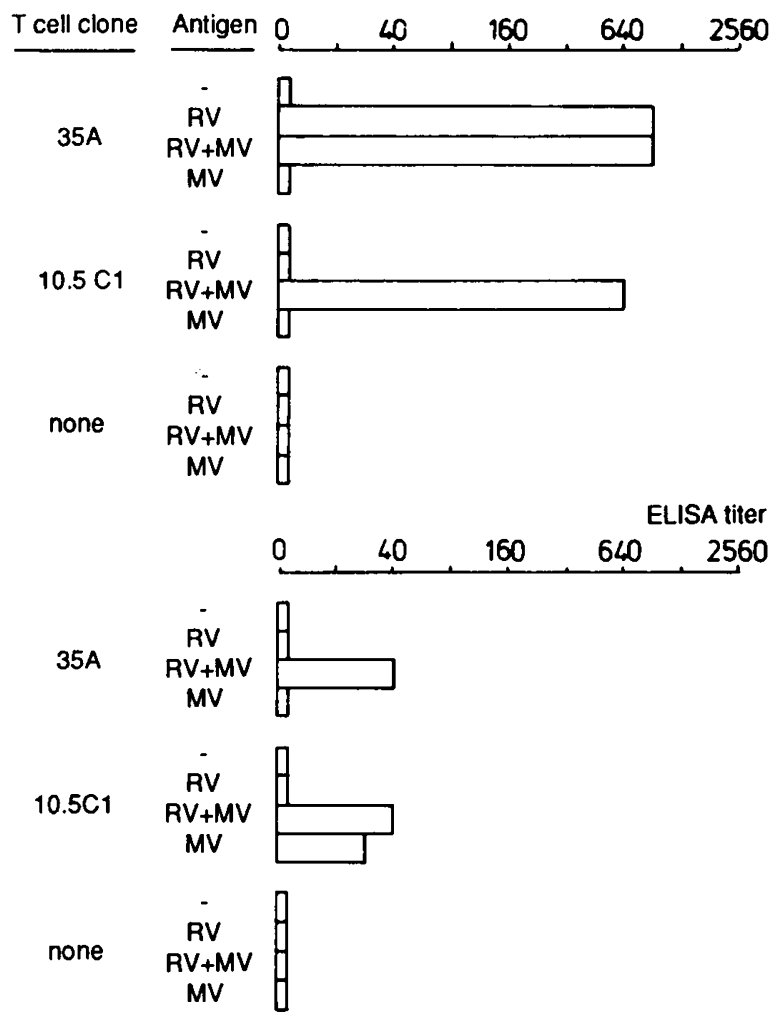

\section{FIGURE 3}

Specificity of the in vitro helper function. Splenocytes of mice immunized with either PM-DKCV or measles virus were depleted of $T$ cells. Non-T cell fractions were mixed $(1: 1)$ and cultured at $4 \times 10^{5}$ cells/well with $10^{2}$ cells/well of a rabies virus-specific $\mathrm{T}$ cell clone $35 \mathrm{~A}$, a measles virus-specific $\mathrm{T}$ cell clone $10.5 \mathrm{Cl}$ or no $\mathrm{T}$ cells in the presence of PMDKCV (RV), measles virus (MV), both antigens (RV + MV) or no antigen $(-)$. After 7 days of culture, supernatant fluids were harvested and then assayed for PM-DKCV binding and/or measles virus-binding IgG in ELISA. The resulis represent the mean antibody titre of supernatant fluids obtained from triplicate cultures.

the human $T$ cell clones that cross-react with different members of the genus Lyssavirus were then shown to reside within the G-protein and the $\mathrm{N}$ protein. Analysis of the polypeptide specificity of the murine $T$ cell clones described here, revealed that: clone AA8 detects an epitope of the M-protein which is expressed by PM, HEP, MOK and DUV6 viruses, clone 35A detects an epitope of the M-protein which is expressed by PM, HEP, ERA, CVS and MOK viruses, and clone BG2 detects an epitope of the G-protein which is expressed by PM, HEP, ERA, CVS and MOK viruses.

In studies characterizing the functional activity of these rabies virus-specific murine $T$ cell clones, we observed that all the three clones were able to mediate a virus-specific DTH response in vivo, which is a characteristic feature of clones belonging to the $T_{H} 1$ subset of $T$ cells (21). In vitro, all clones were shown to be able to assist B cells for specific antibody production against several rabies virus proteins, including glycoprotein-specific rabies virus neutralizing antibodies. The generation of an antibody response in vitro occurred independently from cell growth, since similar results were obtained when the clones were irradiated (data not shown). 

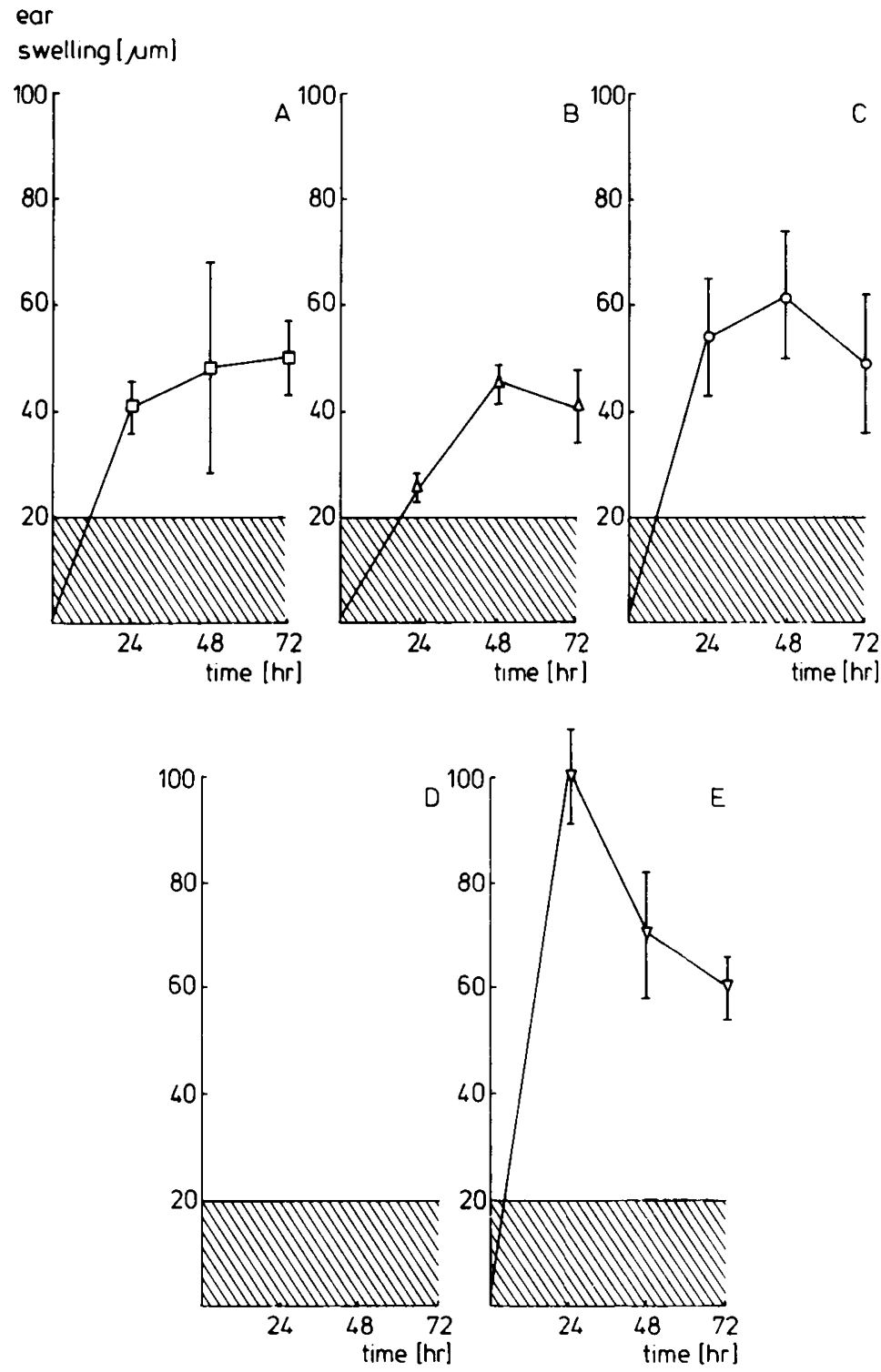

FIGURE 4

DTH response mediated by rabies virus-specific $\mathrm{T}$ cell clones. $1 \times 10^{6}$ viable $T$ cells of clones AA8 (A), 35A (B) or BG2 (C) were inoculated intraveneously in syngeneic BALB/c mice. Medium only was inoculated in mice, which were prior to cell transfer immunized with PM-DKCV (E) or shamimmunized (D). Mice (A, B, C, D, E) were injected intracutaneously with HEP virus (left ear) or with control brain suspension (right ear). Ear swelling was measured at different times after antigen challenge and is expressed in $\mu \mathrm{m}$ as the mean \pm S.D. per group of three mice. Ear swelling caused by injection of control brain suspension did not exceed $20 \mu \mathrm{m}$ and was considered background swelling.

The way in which $T_{H}$ cells assist $B$ cells in their activation and differentiation to antibody-secreting cells is still not completely understood. Two distinct pathways, MHC class II unrestricted (factormediated help) and cognate help respectively have been described (for 
review see 22). Here we have demonstrated for rabies virus-specific $T_{H} 1$ cells (results shown for 35A), in line with observations of others $(23)^{4}$, who demonstrated that $\mathrm{T}_{\mathrm{H}} 1$ cells can activate $\mathrm{B}$ cells by secretion of soluble factors, that help was provided to both rabies virus- and measles virus-specific $B$ cells. That the activation of $B$ cells, and their subsequent production of antibody was not merely the result of activation of bystander $B$ cells was clearly demonstrated by the need to use two antigens simultaneously in culture. Effective $T$ and $B$ cell co-operation between cells of different virus specificity only occurred when both rabies virus and measles virus antigens were present, indicating a necessity for an antigen to activate the $\mathrm{T}$ cell clones and a necessity for the other antigen to render the $B$ cells susceptible for $T$ cell helper activity. However, due to the experimental conditions, we cannot exclude the possibility that the rabies virus-specific $\mathrm{T}_{\mathrm{H}} 1$ clone $35 \mathrm{~A}$ assisted, in addition to factor-mediated help, rabies virus-specific $B$ cells by cognate help. Recent experiments have indeed demonstrated that conjugate formation between $T_{H} 1$ cells and $B$ cells presenting processed antigen can occur (24).

It will 1 be of particular interest to find out whether $T_{H} 1$ cells specific for structural proteins other than the G-protein will confer protective immunity against rabies virus infection in vivo. Since in vivo micro-environments exist, where antigen-specific $\mathrm{T}$ and $\mathrm{B}$ lymphocytes come close together, it is likely that in addition to cognate help, factormediated help resulting in a VNA response as demonstrated here, would occur also in vivo. In this respect it is promising to note that the $T$ cell clones described here recognize rabies virus antigen in vivo and are able to migrate to the site of virus entry.

\section{ACKNOWLEDGEMENTS}

We thank Dr. H. Ertl for helpful suggestions and discussion and Ms. C. Kruyssen and Ms. M.C. Eskens for preparing this manuscript.

\section{REFERENCES}

1. Kawai A: Transcriptase activity associated with rabies virion. J Virol $24: 826-835,(1977)$.

2. Turner GC: Immune response after rabies vaccination. Basic aspects. Ann Inst Pasteur 136E:453-460, (1985).

3. Wiktor TJ, Gyorgy E, Schlumberger HD, Sokol F, Koprowski H: Antigenic properties of rabies virus components. J Immunol 110:269-276, (1973).

4. Cox JH, Dietzschold B, Schneider LG: Rabies virus glycoprotein. II. Biological and serological characterization. Infect Immun 16:754-759, (1977).

5. Wiktor TJ, MacFarlan RI, Reagan K, Dietzschold B, Curtis P, Wunner WH, Kieny MP, Lathe R, Lecoc IP, Machett M, Moss B, Koprowski H: Protection from rabies by vaccinia virus recombinant containing the rabies virus glycoprotein gene. Proc Natl Acad Sci USA 81:7194-7198, (1984).

6. Wiktor $\mathrm{TJ}$, Doherty $\mathrm{PC}$, Koprowski $\mathrm{H}$ : In vitro evidence of cell-mediated immunity after exposure of mice to both live and inactivated rabies virus. Proc Natl Acad Sci USA 74:334-338, (1977).

7. Cho S, Narahara H, Mifune K, Kawai A: Murine T cell clones directed to rabies virus. Isolation and some of their properties. J gen Virol $68: 1115-1123$, (1987). 
8. Celis E, D. OU, Dietzschold B, Koprowski H: Recognition of rabies and rabies-related viruses by $T$ cells derived from human vaccine recipients. J Virol 62:3128-3134, (1988).

9. Celis E, Karr RW, Dietzschold B, Wunner WH, Koprowski H: Genetic restriction and fine specificity of human $\mathrm{T}$ cell clones reactive with rabies virus. J Immunol 141:2721-2728, (1988).

10. Dietzschold B, Wang H, Rupprecht CE, Celis E, Tollis M, Ertl H, Heberkatz E, Koprowski H: Induction of protective immunity against rabies by immunization with rabies virus ribonucleoprotein. Proc Natl Acad Sci USA 84:9165-9169, (1987).

11. Mifune K, Takeuchi E, Napiorkowski PA, Yamada A, Sakamoto K: Essential role of $\mathrm{T}$ cells in the postexposure prophilaxis of rabies in mice. Microbiol Immuno1 25:895-904, (1981).

12. Prabhakar BS, Fisherman HR, Mathanson N: Recovery from experimental rabies by adoptive transfer of immune cells. J gen Virol 56:25-31, (1981).

13. Smith JS: Mouse model for abortive rabies infection in the central nervous system. Infect Immun 16:297-308, (1981).

14. UytdeHaag FGCM, Osterhaus ADME, Loggen HG, Bakker RHJ, Van Asten JAAM, Kreeftenberg JG, Van der Marel P, Van Steenis B: Induction of antigenspecific antibody response in human peripheral blood lymphocytes in vitro by a dog kidney cell vaccine against rabies virus (DKCV). J Immunol 131:1234-1239, (1983).

15. Bunschoten H, Klapmuts RJ, Claassen IJThM, Reyneveld SD, Osterhaus ADME, UytdeHaag FGCM: Rabies virus-specific human $T$ cell clones provide help for an in vitro antibody response against neutralizing antibody-inducing determinants of the viral glycoprotein. J gen Virol 70 : in press.

16. Van Wezel AL, Van Steenis B, Hannik CA, Cohen H: New approaches to the production of concentrated and purified inactivated polio and rabies tissue culture vaccines. Dev Biol Stand 41:159-168, (1978).

17. De Vries P, Van Binnendijk RS, Van der Marel P, Van Wezel AL, Voorma HO, Sundquist B, UytdeHaag FGCM, Osterhaus ADME: Measles virus fusion protein presented in immune-stimulating complex (iscom) induces haemolysis-inhibiting and fusion-inhibiting antibodies, virus-specific $\mathrm{T}$ cells and protection in mice. J gen Virol 69:549-559, (1988).

18. Dietzschold B, Lafon $M$, Wang $\mathrm{H}$, Otvos $\mathrm{Jr} \mathrm{L}$, Celis $\mathrm{E}$, Wunner $\mathrm{WH}$, Koprowski $\mathrm{H}$ : Localization and immunological characterization of antigenic domains of the rabies virus internal $\mathrm{N}$ and $\mathrm{NS}$ proteins. Virus Res 8:103-125, (1987).

19. Bunschoten H, Gore M, Claassen IJThM, UytdeHaag FGCM, Dietzschold B, Wunner WH, Osterhaus ADME: Characterization of a new virus neutralizing epitope that denotes a sequential determinant on the rabies virus glycoprotein. J gen Virol 70:291-298, (1989).

20. Wiktor TJ, Koprowski H: Monoclonal antibodies against rabies virus produced by somatic cell hybridization: detection of antigenic variants. Proc Nat1 Acad Sci USA 75:3938-3942, (1978).

21. Cher DJ, Mosmann TR: Two types of helper T cell clone. II. Delayedtype hypersensitivity is mediated by $\mathrm{T}_{\mathrm{H}}{ }^{1}$ clones. J Immunol 38:36883694, (1987). 
22. Abbas AK: A reassessment of the mechanisms of antigen-specific $\mathrm{T}$ cel1 dependent $B$ cell activation. Immunol Today 9:89-94, (1988).

23. Killar L, MacDonald G, West J, Woods A, Bottomly K: Cloned Iarestricted $\mathrm{T}$ cells that do not produce Interleukin 4 (I14)/B cell stimulatory factor 1 (BSF-1) fail to help antigen-specific B cells. J Immunol 138:1674-1679, (1987).

24. Sanders VA, Fernandez-Botran R, Coffman RL, Mosmann TR, Vitetta ES: A single antigen-specific B cell can conjugate to either a type 1 or a type 2 helper T cell. Proc Natl Acad Sci USA 85:7724-7728, (1988).

Please address reprint requests to:

Hans Bunschoten

Department of Immunobiology

National Institute of Public Health and Environmental Protection

P.O.Box 1

3720 BA Bilthoven The Netherlands 